\title{
Prometheus Myth: The Image of Fire in Modern and Contemporary Arabic Poetry
}

\author{
Sherin ABDEL GHAFFAR \\ University of Assiut
}

\section{Introduction}

Modern and contemporary Arab poets have been greatly inspired by Greek mythology. Badawi (1993) reminds us of modern Arab poets' profound identification with the mythical revolutionary figures of different myths or legends such as Prometheus, who signifies the possible emergence of an Arab poet as a savior who calls for revolutions against injustices and tyrannies in not only the Arab world, but also all over the universe (39). Benefiting from this mythical story, modern and contemporary Arab poets keep burning and sacrificing in order to enlighten the scattered dark places and to encourage other people to do the same for the purpose of human dignity and survival.

The Prometheus myth has inspired modern and contemporary Arab poets who have been searching for a model through which they can represent their desire of to break away from restraints and barriers. Among those who have employed this myth in their verse are: Abu-El Qasem Al Shabi (1909 - 1934), Abdel Wahab El Bayati (1926 - 1999), and Ahmed Abdel Moaty Hegazy (1935 - _ )

Poets, who have employed myth in their poems, are particularly apt to use extended images to represent this theme. For example, they have evoked the mythical image of fire to refer to the myth of Prometheus. The present study shows how Abu-El Qasem Al Shabi, Abdel Wahab El Bayati, and Ahmed Abdel Moaty Hegazy managed to adopt the myth of Prometheus in their poems. 


\section{Prometheus Myth}

\section{Prometheus Myth}

Greek mythology has long fascinated humankind. One of the stories that caught the attention of writers was the myth of Prometheus. According to the early Greeks, Prometheus played the role of the fire-bringer, who brought the sacred fire from the sky to the earth for the purposes of purgation and salvation. Prometheus stands as a symbol of rebellion against power as well as a benefactor of mankind. At the root of this myth is:

the sublime conception of the passage from slavery to freedom; of the spirit which refuses any longer to remain the unquestioning slave of the caprices of a tyrant and demands to obey no power but that which is the embodiment of . . . justice, that whose service is perfect freedom and the fullness of life. (qtd.in Jayyusi 1977, 741).

It is this spirit of myth that has permeated much of modern and contemporary Arabic poetry.

Prometheus, the greatest of the Titans, taught men many useful skills: architecture, mathematics, astronomy, metallurgy, and medicine. Zeus, the chief of the Greek gods, became angry at Prometheus for teaching men all the skills that would make them powerful.

Having deceived Zeus twice on behalf of mankind, Prometheus was severely punished. The first time Prometheus attempted to deceive Zeus was at Mecone, when Prometheus was chosen by gods as an arbiter in a dispute that arose over the sacrifices between gods and men. Prometheus tricked the gods into eating bare bones instead of good meat by dividing the sacrificial bull into two parts: a part where he wrapped all the flesh of the bull up in the skin, while in the other part he put the bones carefully concealed in a rich layer of fat. Zeus was deceived by this trick, and chose the bones. Accordingly, Zeus withheld fire (the symbol of enlightenment 


\section{Sherin ABDEL GHAFFAR}

and wisdom) from men in order to get revenge. "Let them eat their flesh raw," he declared. However, Prometheus managed to deceive Zeus for the second time by stealing fire from the workshop of Hephaestus (the Greek god of fire), hiding it in a hollow stalk, and giving it back to men.

To get revenge, Zeus tried to trick Epimetheus, Prometheus's brother, into accepting Pandora (a beautiful but mischievous woman created by Zeus) as a gift. Unfortunately, Epimetheus refused the gift. Having failed to trick Epimetheus, Zeus chained Prometheus to a pillar in the Caucasian mountains, where an eagle would eat the liver of Prometheus all day long. Then, during the night, the liver would become whole again ready to be eaten again, and so on. Years passed, and Epimetheus married Pandora in an attempt to free his brother. However, Pandora opened the famous box in which Prometheus had shut up all the evils that would plague men: insanity, old age, labor, passion, vice and sickness. Years later, Heracles (the son of Zeus) killed the eagle and set Prometheus free.

\section{Abu-El Qasem Al Shabi}

The first Arab poet who employed the Prometheus myth in his poems was the Tunisian poet, Abu-El Qasem Al Shabi. Al Shabi is considered one of the pioneers of modern Arab poetry. He wrote his poems when Tunisia was struggling under the French colonialism in the early $20^{\text {th }}$ century. Thus, his poetry was highly influenced by the state of Tunis: the miserable social conditions, and political weakness that resulted from colonialism.

In spite of his pain and disappointment, Al Shabi had a positive, optimistic view. He called himself "Titan", evidence that he would defeat all his enemies. He borrowed the character of Prometheus who faced all challenges (though he was severely punished by gods). Al Shabi chose the character of Prometheus as a symbol of rebellion and resistance; he refused to surrender to his enemies; he dreamt, instead, of achieving victory as long as he was still alive. 


\section{Prometheus Myth}

The poems of Al Shabi capture the emotions of Tunisian protesters in their struggle for democracy, and prove a powerful, unifying cry for freedom. Mohamed Mandour states, "the spirit of Abu-El Qasem is inspired by the glorious days lived by the people of Tunisia, as he fights tyranny without feeling any kind of weakness or submissiveness" (qtd. in Kamel 2013, 125; my translation).

In his famous poem "The Hymn of the Titan" or "Thus Prometheus Sang", Al Shabi uses the myth of Prometheus as a symbol of rebellion against power. He believes that the path of sacrifice leads to nothing but survival.

The poet expresses his worry about the envy of his enemies who wish to kill eat his flesh. This is a brutal expression of the hostility between the poet and his enemies. In this poem, Al Shabi expresses his insistence upon arousal. He aims at provoking the Tunisian people to rise in order to face the French colonialism:

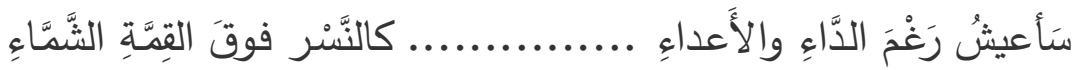

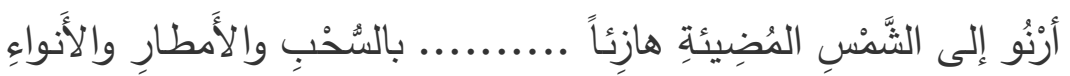

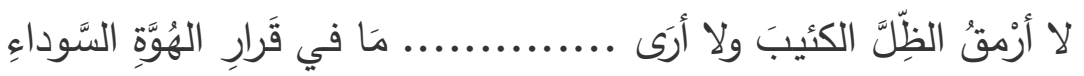

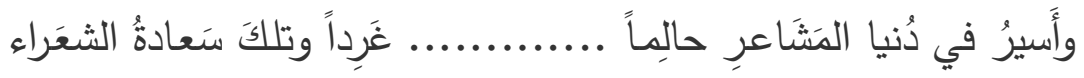

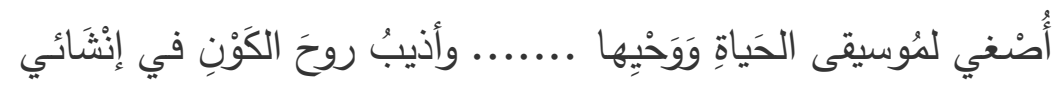

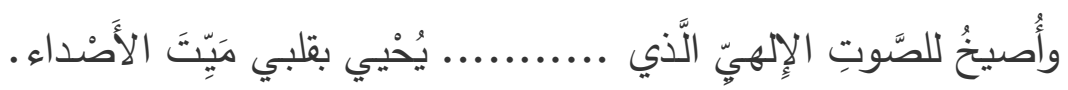

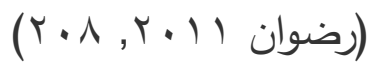

In these lines, the poet is not afraid of his enemies; he is like the solid rock that cannot be destroyed. He says that he is going to live strong like an 


\section{Sherin ABDEL GHAFFAR}

eagle that hovers high upon the top of the hills, looking at the brightening sun, making fun of the clouds that hides the truth. He will not look at the shadows or the black far holes. He will not be defeated; he will still be longing for freedom through listening to the voice of dignity that awakens weak hearts. Thus, these lines demonstrate how much the poet is confident of his victory no matter how strong his enemies are.

Then, in the second stanza, the poet attempts to challenge fate as well as his enemies:

$$
\begin{aligned}
& \text { وأقولُ للقَََرِ الَّنَي لا ينثني ......... عَنْ حَرْبِ آمالي بكلِّ بَلاعِ } \\
& \text { لا يُطْفِيٌُ اللَّهبَ المؤجَّجَ في دمي.. موجُ الأسى وعواصفُ الأَّراءِ } \\
& \text { فاهدم فؤادي ما استطعتَ فانَّهُ .... سيكون مثلَ الصَّخرة الصَّمَّاءِ } \\
& \text { لا يعرفُ الثَّكوى الذَليلَة والبكا ..... وضراعَة الأَطفالِ والضّعفاءِ } \\
& \text { ويعيشُ جبَّارًا يحدِّق دائماً ........ بالفجر بالفجرِ الجميلِ النَّائي }
\end{aligned}
$$

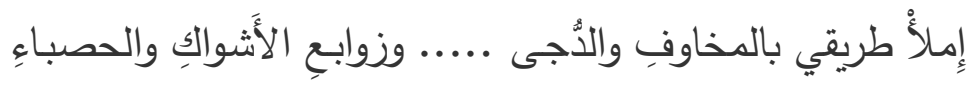

$$
\begin{aligned}
& \text { وانْشر عليه الرُعب واثر فوقه }
\end{aligned}
$$

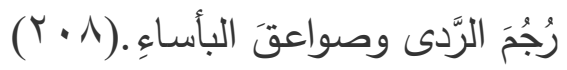

He personifies fate and talks to it, telling it that he will face him. He believes that destiny will not be able to put off the burning flames in his blood no matter how many misfortunes he will face. Then he challenges fate and asks him to break his heart if he wishes, for his heart, like a solid rock, will not be destroyed. He says that he will not give up, be humiliated, or cry, but will live like a 'Titan', waiting for a new day to come. He will not be afraid of the darkness or harmful thrones that hinder his way as he knows he will overcome all these obstacles. He emphasizes that he would 


\section{Prometheus Myth}

challenge fear in the same way he would challenge death. He uses the words "destroy", "fill", and "spread" as synonyms for "challenge."

In the third stanza, the poet expresses an optimistic view of the future:

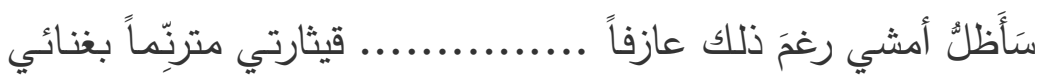

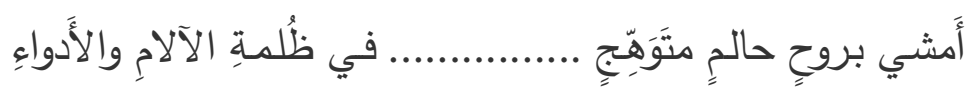

$$
\begin{aligned}
& \text { النُّر في قلبي وبينَ جوانحي ...... فَعَلامَ أخشى السَّيرَ في الظلماءِ }
\end{aligned}
$$

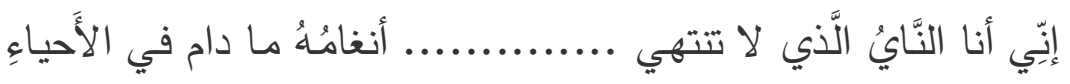

$$
\begin{aligned}
& \text { وأنا الخِضَمُ الرحْبُ ليس تزيدُهُ ................ إلَّ حياةً سَطْوةُ الأَنَواءِ } \\
& \text { أَمَّا إذا خمدت حياتي وانقضى ......... عُمُري وأخرسَتِّ المنيَّةُ نائي }
\end{aligned}
$$

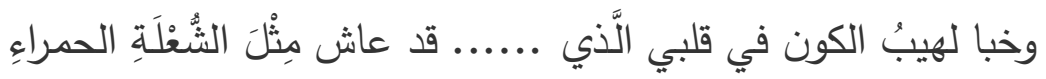

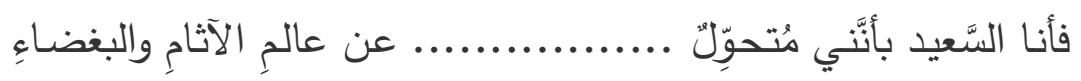

$$
\begin{aligned}
& \text { لأذوبَ في فجر الجمال السرمديّ ......... وأرتوي من مَنْهَلِ الأَضواءِ. } \\
& (Y \cdot 9)
\end{aligned}
$$

In these lines, the poet believes he will survive. He compares himself to a star that is not afraid of walking in the dark. He also compares himself to the flute whose tunes do not stop as long as those who play it are alive. However, if his life ends, and the flame of the universe (that has lived like the red fire), he would be happy he is leaving this sinful world in order to dissolve in the dawn of eternal beauty and drink from the source of light. 


\section{Sherin ABDEL GHAFFAR}

Al Shabi concludes his poem by declaring challenge once again:

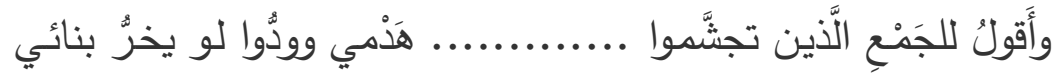

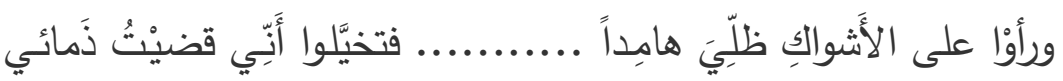

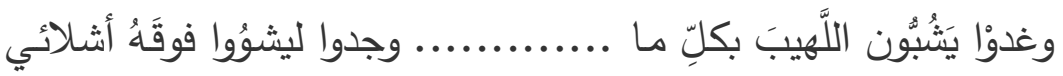

$$
\begin{aligned}
& \text { ومضَوْا يَمُدُونَ الخُوَانَ ليأكلوا ........... لحمي ويرتشفوا عليه دِمائي }
\end{aligned}
$$

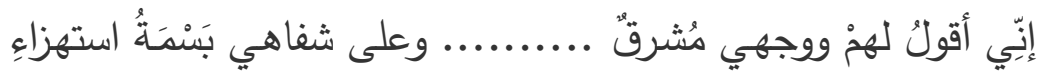

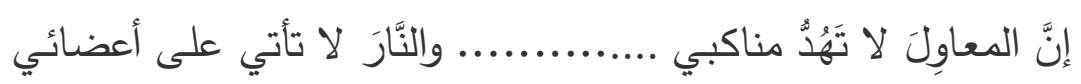

$$
\begin{aligned}
& \text { فارموا إلى النَّار الحشائشَ والعبوا ..... يا مَعْشَرَ الأَطفالِ تحسَ سَمائي }
\end{aligned}
$$

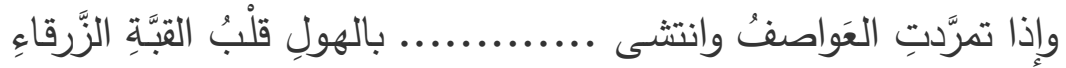

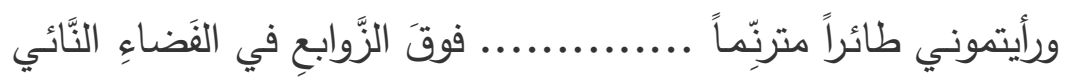

$$
\begin{aligned}
& \text { فارموا على ظلِّي الحجارةَ واختقوا ...... خَوْفَ الرّبِّاحِ الْهوجِ والأَنواءِ }
\end{aligned}
$$

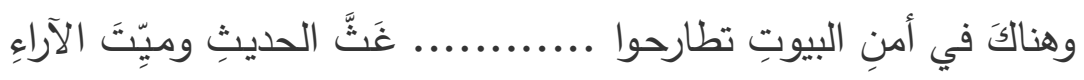

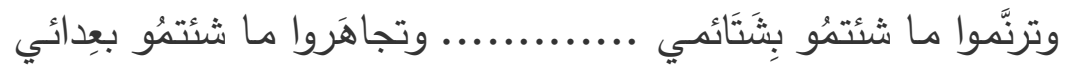

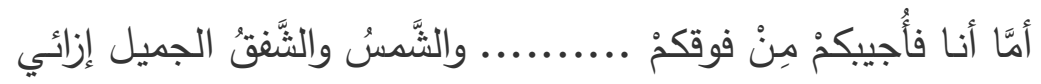

$$
\begin{aligned}
& \text { مَنْ جَاشَ بالوحي المقدَّسِ قلبُه ............... لم يحتقل بحِجَارٍِ الفلتاه. } \\
& (1 \cdot-r \cdot 9)
\end{aligned}
$$

In these lines, the poet addresses the enemies of his country, saying that this injustice will not last long, and that their actions will not stop his enthusiasm. He says that fire will not eat his body. He also points out that his enemies can throw grass into the fire, or even let their kids play under the sky; he will not pay attention to the stones of the stray. He then compares himself to the wind that will hit anything that comes in its way. 


\section{Prometheus Myth}

Thus, he advises his enemies to hurry up and run before he hits them. He insists that his country will be free of colonialism.

\section{Abdel Wahab El Bayati}

Another pioneer to employ the Prometheus myth in his poems was the Iraqi poet, Abdel Wahab El Bayati, who considered himself himself as the "Prometheus/Fire-stealer." In The Death of the Myth, El Bayati says: "the poetic fires which have been inflamed during the forties and the beginnings of the fifties are still alive and blazing and they finally turned to be a forest of flame" (qtd. in Etman 2011, 148).

In his poem, "The Worshipped," El Bayati says:

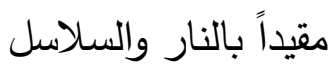

$$
\begin{aligned}
& \text { أعود للمنفى مع الطيور والقوافل } \\
& \text { منتظراً قيامة الشاعر والساحر والمقاتل } \\
& \text { أعبد في عينيك هذي النار } \\
& \text { ووجهك الثاحب والضفيرة } \\
& \text { والغربة ـ الطفولة ـ الأسطورة } \\
& \text { حلفت بالمعابد المكسوة القباب بالذهب } \\
& \text { بالحرف والغربة والسفر } \\
& \text { أن أرحل الليلة نحو مدن الحلم وأبني لك أهراماً على الفرات } \\
& \text { في نار عصور البعث والثورة والأمل. (البياتي ^ . . rب, ماب-1 1) }
\end{aligned}
$$




\section{Sherin ABDEL GHAFFAR}

In these lines, the speaker is imprisoned in fire and chains, waiting for the rebels to rescue him. The poet uses such words as "fire," "resurrection," "fighter," "revolution," and "hope" as symbols of the Arab revolution.

In another poem "The Golden Locust," Al Bayati seeks to find Prometheus, the revolutionary who would steal fire from the sun and return it to mankind. He uses metaphors that symbolize survival, waiting, and suffering:

$$
\begin{aligned}
& \text { مددت للشمس يدي ، فاخضرت الأشجار } \\
& \text { أمسكت بالنهار } \\
& \text { وهو يولي هاربا في عربات النار } \\
& \text { توهج الرماد في أصابعي وطارت العنقاء. ( V9 ) }
\end{aligned}
$$

Then, he talks about the destiny of anyone who tries to act as a benefactor of humankind. He states that he is to be punished, just like Prometheus, by being tied to a rock to be eaten by an eagle.

$$
\begin{aligned}
& \text { بكى أبو العلاء }
\end{aligned}
$$

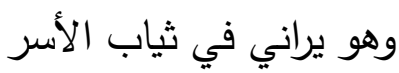

$$
\begin{aligned}
& \text { ينهش صدري النسر } \\
& \text { منتظراً مع الملايين طلوع الفجر ـ (r/ ( ) }
\end{aligned}
$$

Here, the poet uses such metaphors as "the eagle eats my chest" and "waiting with millions for dawn" to show the sacrifice of the rebel who refuses to give up and dreams of victory despite his great suffering. 


\section{Prometheus Myth}

In the "Fire Stealer," Al Bayati expresses a negative, pessimistic tone when he shows Prometheus as a weak, desperate person. In his poem, $\mathrm{Al}$ Bayati has a negative, pessimistic view. He uses the myth of Prometheus in a passive way when he talks about the rage of the Gods. He believes that the will of people has collapsed, as the "Fire-Stealer" can no longer benefit men for he is cursed now by gods:

$$
\begin{aligned}
& \text { داروا مع الثمس فانهارت عزائمهح } \\
& \text { وعاد أولهم ينعي على الثاني } \\
& \text { وسارق النارِ لم يبرح كعادته } \\
& \text { يسابق الريح من حان إلى حان }
\end{aligned}
$$

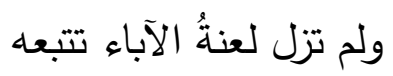

$$
\begin{aligned}
& \text { وتحجب الأرض عن مصباحه القاني } \\
& \text { ولم تزل في السجون السود رائحة } \\
& \text { وفي الملاجئ من تاريخه العاني } \\
& \text { مشاعل كلما الطافوت أطفأها } \\
& \text { عادت تضيء على أشلاء إنسان. (البياتي ^ . . بأ, اء ( ) }
\end{aligned}
$$

The poet insists that the age of heroism has faded away. He adds that coffins are better than fire and knowledge:

$$
\text { عصر البطولات قد ولى وها أنذا }
$$




\section{Sherin ABDEL GHAFFAR}

$$
\begin{aligned}
& \text { وحدي احترقت ! أنا وحدي ! وكم عبرت } \\
& \text { بي الثموس ولم تحفل بأحزاني } \\
& \text { إني غفرت لهم } \\
& \text { إني رثيت لهم! } \\
& \text { إني تركت لهم }
\end{aligned}
$$

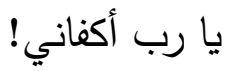

$$
\begin{aligned}
& \text { فلتلعب الصدفة العيماء لعبتها } \\
& \text { فقد بصقت على قيدي وسجاني } \\
& \text { وما علي إذا عادوا بخيتهم }
\end{aligned}
$$

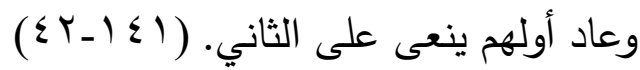

Similarly, in his poem, "Lament for the June Sun," which was published a year after the 1967 defeat, Al Bayati expresses his pessimistic view when he uses the image of fire to mourn "a generation of meaningless death":

$$
\begin{gathered}
\text { آه يا قبر حكيم نام بين الفقراء صامتا يلبس أكفان الحداد } \\
\text { قم تحدثا يشعل نار } \\
\text { نحن موتى }
\end{gathered}
$$

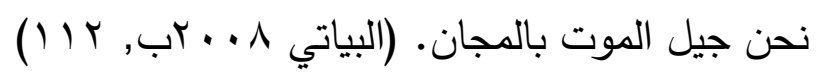




\section{Prometheus Myth}

In the lines above, the poet criticizes the Arab leaders for deceiving their people and not telling them the reality of the situation.

In his poem, "An Autobiography of the Fire-Stealer", El Bayati uses the myth of Prometheus as a symbol of the Arab revolution. Just like Prometheus who saved humanity from darkness, the Fire-Stealer in this poem is compared to the savior that the chained land needs in order to be freed. However, the poet here gives a tragic picture of the world that is dying:

$$
\begin{aligned}
& \text { كان سارق النار مع الفصول يأتي }
\end{aligned}
$$

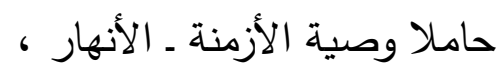

$$
\begin{aligned}
& \text { يأتي رائيا : } \\
& \text { يهمس في سباق خيل البشر الفانيين } \\
& \text { في توهج الأرض التي حل بها - - ال } \\
& \text { بالرجل الثمس ، وبالقيثارة المرأة } \\
& \text { ، حرين من الأغلال }
\end{aligned}
$$

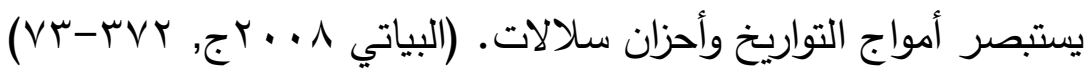

The poet then describes the Fire-Stealer in the following lines:

$$
\text { وكانت يده تمر فوق شعرها في دوامة الرقص الثاحب في قرارة الكأس ، وجه }
$$




\section{Sherin ABDEL GHAFFAR}

$$
\text { وفوق الليل والجليد والدخان. (rvo) }
$$

This pale face of the Fire-Stealer, as stated in the above lines, signifies sorrow and loss of hope.

Then, Al Bayati shows the Fire-Stealer as a lonely person when he says:

$$
\text { رأيت، : سارق النار على كرسيه في زاوية }
$$

Later, the poet returns to the bar, where he has left the Fire-Stealer, only to find him dead:

$$
\begin{aligned}
& \text { رأيت' وجهه الشاحب في قرارة الكأس } \\
& \text { وفي المرآة } \\
& \text { كان ميتا. (rVN) }
\end{aligned}
$$

The Fire-Stealer has died, as (in this world) there is no 'Heracles' who would set him free. This is an emphasis of the end of the age of heroism.

\section{Ahmed Abdel Moaty Hegazy}

With the passing of time, the concept of fire has come to denote a new meaning; it symbolizes knowledge and science. Hegazy dedicated this poem to Taha Hussein (the Dean of Arabic Literature). Hegazy calls Taha Hussein the 'fire-stealer'. He believes Hussein (though being blind) went to Paris in order to steal the fire of enlightenment and give it to the Arab 


\section{Prometheus Myth}

nation. He even compares him to the blind prophet who would lead people to light:

$$
\begin{aligned}
& \text { سارق النار } \\
& \text { آفةُ أن يكحِّله الله بالظلمة السرمديةِ، } \\
& \text { أم آيةٌُ } \\
& \text { أن يقود خطانا إلي النور هذا النبي الضريزٌ؟! } \\
& \text { كروان يجدِف في الظلماتِ، } \\
& \text { يفتش عن مدن ضائعاتٍ } \\
& \text { وعن سفن غارقاتٍ } \\
& \text { ويقرأ ماغيَّب الموت من أوجدٍ } \\
& \text { ويكلم من في القبوز! (حجازي (1) }
\end{aligned}
$$

Then, Hegazy argues that Hussein (following the path of Prometheus and Abu ElAlaa' AlMaari) wanted to get people out of the age of darkness and make them live in the age of knowledge and enlightenment:

$$
\begin{aligned}
& \text { أيُّ لغزٍ سيلقي به حين يدخل قلعتهح } \\
& \text { فارع الطول، صلت الجبينِ } \\
& \text { يزلزل عَرشهمو بالسؤالِ، } \\
& \text { ويسرق نيرانهم، ويطيز ! }
\end{aligned}
$$


Sherin ABDEL GHAFFAR

$$
\begin{aligned}
& \text { كان يسري بنا في الأُجنَّةِ } \\
& \text { يخرجنا من عصور ، ويدخلنا في عصورٌ } \\
& \text { وكأنَّا علي رفرف من شعاع نطيرُ ، } \\
& \text { ونعرج في سُلَّم من سطوز } \\
& \text { والمعريٌٌ يسبق طه. } \\
& \text { وطه يراه، ويركض في إثره. }
\end{aligned}
$$

\section{Conclusion}

The Greek myth of Prometheus has been a source of inspiration for modern and contemporary Arab poets. They have considered themselves as 'Prometheus/Fire-Stealer'. 'Stealer of the fire' is an expression that has only come to appear in modern and contemporary Arabic poetry. Etman (2011) points out that the expression of the 'fire-stealer' "originally means nothing in Arabic traditional poetic language. But now, with the Greek mythological background of Modern Arabic Poetry, it means a lot" (149). It means resurrection, rebellion, enlightenment, knowledge, hope, .....etc.

\section{References}

Asimov, Isaac. 1969. Words from the Myths. Boston: Houghton Mifflin Company.

Badawi, M.M. 1993. A Short History of Modern Arabic Literature. New York: Oxford UP.

Etman, Ahmed. 2011. "Translation at the Intersection of Traditions: The Arab Reception of the Classics." A Companion to Classical

Receptions. Ed. Lorna Hardwick and Christopher Stray: 


\section{Prometheus Myth}

Blackwell, 141-52.

Graves, Robert. 1995. The Greek Myths. Moyer Bell Ltd.

$$
\begin{aligned}
& \text { البياتي, عبدالو هاب. } 1 \text {. . بأ. دبوان عبدالوهاب البياتي. المجلد الأول. دار العودة - بيروت. }
\end{aligned}
$$

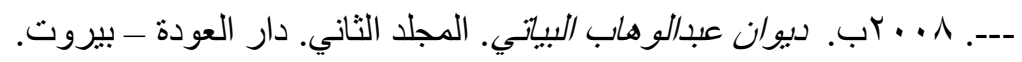

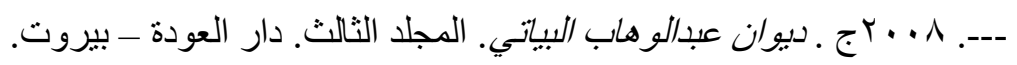

$$
\begin{aligned}
& \text { الطريفي, يو سف عطا. با ا ـ ؟ أبوالقاسم الثابي: حياته وشعره. الأردن, عمان: الأهلية للنشر } \\
& \text { والتوزيع. } \\
& \text { حجازي, أحمد عبدالمعطي. 11 + r. "سارق النار ." القاهرة: الأهر ام اليومي, اب مارس. } \\
& \text { رضوان, محمد. II لـ. ديوان أبوالقاسم الثابي: شاعر الثورة والحب والحرية: حياته .. ديوانه .. } \\
& \text { أعماله المجهولة. دمشث - القاهرة: دار الكتاب العربي. }
\end{aligned}
$$

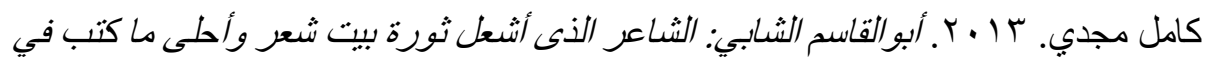

$$
\begin{aligned}
& \text { الحرية والحب والجمال. دمشق - القاهرة: دار الكتاب العربي. }
\end{aligned}
$$

